\title{
Building Potentials of Permis and Rajik Villages as Ecotourism Villages in South Bangka Regency
}

\author{
DarmanSaputra \\ Management, Faculty Economic, University \\ Bangka Belitung \\ Indonesia \\ saputradarman1988@gmail.com
}

\author{
Julia \\ Accounting, Faculty Economic, University \\ Bangka Belitung \\ Indonesia saputrajulia07@gmail.com
}

\begin{abstract}
Community-based ecotourism is an effort to develop villages through the tourism sector, not only to utilize tourism resources that are still maintained but also contributing fully to environmental friendliness and the community as an increase in community welfare. Permis Village and Rajik, Bangka Selatan Village, have a fascinating culture and nature. They have started to be developed as ecotourism areas. Still, they have many problems, both from the environmental aspect and management aspects to human resource aspects, so that the region's tourism activities have not yet developed. Therefore, research is needed to analyze the potential for the development of social economy-based ecotourism in Permis Village and Rajik Village. Thus, an analysis is carried out on the object and tourist attraction aspects, social aspects, management aspects, and community empowerment aspects. In collecting data, the method used is field observation, interviews with informants determined by purposive sampling, and questionnaires to respondents selected by random sample. Data analysis using quantitative methods and qualitative descriptive. Based on the results of the research, it can be concluded that Permis Village and Rajik Village have good potential to be developed as community-based ecotourism areas because they not only have tourism resources in the form of natural and cultural tourism but also have potential community resources to be empowered in these tourism activities. Also, there are several programs and government policies to develop ecotourism in the region.
\end{abstract}

Keywords: Ecotourism, Community-Based Ecotourism, Permis Village and Rajik Village

\section{INTRODUCTION}

Tourism is a phenomenon that arises because of the interaction between tourists, service providers/tourism industry, and the government in providing facilities and services that support tourism activities(Ismayanti 2010; Wardhani and Valeriani 2016). These various interactions form a system that is interconnected with one another. According to Mason (2012) and Gunn (2014), the tourism system is developed through a linear supply and demand approach.
The stock component consists of attraction, accommodation, transportation, service, information, and promotion. Meanwhile, the demand component is related to tourism demand originating from tourists [5]. In this case, the demand component acts as a market, which determines what tourists want, their needs, and their ability to pay. Although the tourism system is described as a closed system, this model can analyze essential components in attracting a tourist destination(Fajriasanti 2010; Lew and McKercher 2006). Three tourism activities can strongly support the CBT concept, namely exploration (adventure travel), cultural tourism (cultural tourism), ecotourism (ecotourism)[8].

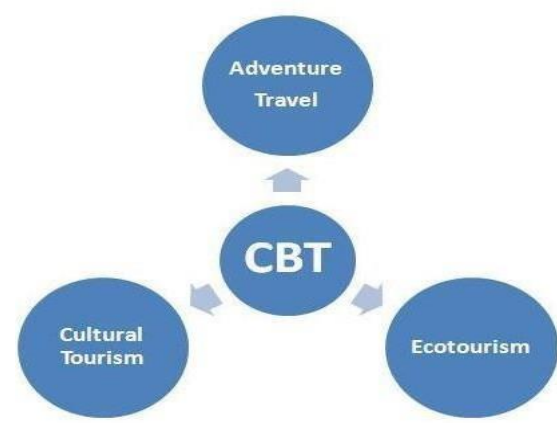

Fig. 1. Concept of CBT

In its development, tourism has several forms, one of which is community-based tourism. Community-Based Tourism, or what is often referred to as Community Based Tourism (CBT), is a form of tourism managed by local communities emphasizing the principles of environmental, social, and cultural sustainability to help tourists understand and learn about the ways of life of local communities. CBT aims to build and strengthen organizational capabilities in local communities. This is what distinguishes it from conventional tourism, which maximizes profits for investors (mass tourism). CBT prioritizes improving community welfare through empowering local communities (Suansri 2003; Mualisin 2017). 
According to Okazaki (2008), the concept of CBT has advantages, including the following: (a) there are local resources that are owned and managed by local communities. These local resources are not only limited to the community but also include the natural environment, infrastructure, and local culture; (b) the existence of local responsibility, meaning that management is carried out by the local community so that the community can be more responsible; (c) there is community involvement in CBT that can protect and protect the natural environment and local culture; (d) allow for different tourism management systems between regions. This is adjusted to the social and economic conditions of the community so that people can maintain and manage their assets according to local wisdom.

The foundation of a traveler town is one shape of actualizing CBT. Through the development of a tourism village, it is hoped that there will be an equal distribution of welfare, which is in accordance with the concept of sustainable tourism development. In expansion, the presence of a visitor town is able to protect the culture of rustic community's actors of tourism activities in their village (Susyanti 2014; Komariah, Saepudin, and Yusup 2018).

Permis Village, SimpangRimba District, Central Bangka Regency has a lot of potentials that can be developed in the context of village development. The central government's plan is to build a nuclear power plant which will later supply electricity to the islands of Bangka and Sumatra as well as in Malaysia. Then the development of transportation, namely the construction of a bridge between the two provinces, namely South Sumatra and South Bangka, will facilitate logistics in and out of the Bangka region. Permis Village and Rajik Village become one unit that has tremendous tourism potential, and if it collaborates, it will certainly create a very amazing tourist center. Rajik Village also has tourism potential such as AkekAntakBatuBedaun Beach, mangrove tourism, hills of clean water sources, oil palm planting areas, and others.

With the existence of a "Tourism Village" based on culture and local wisdom, a travel pattern can be formed which is closely related to the determination and development of spots, points of interest, and photo spots, which are expected to integrate all the tourism potential in Permis and Rajik Villages so that they can build villages and drive the village economy through tourism.

\section{LITERATURE REVIEW}

The development of tourist destinations is one way to make the environment more advanced, good, and useful for all groups. Suwantoro (2002) and Hartini (2011)argues that several forms of tourism products that have the potential to be developed are cultural tourism, ecotourism, marine tourism, adventure tourism, agro-tourism, and tourism. Villages (village tourism), gastronomy (culinary tourism), and spiritual tourism (spiritual tourism). Meanwhile, in Permendagri No. 33 of 2009 concerning Guidelines for the Development of Ecotourism in the Regions in Article 2 explains that the types of ecotourism in the regions are marine ecotourism, forest ecotourism, mountain ecotourism, and/or karst ecotourism.

The actors of ecotourism are the government, local governments, businesses, and communities engaged in tourism [16]. A pattern like this can also be developed by several villages in Indonesia, which have an appeal to maximize the role of community empowerment. Widiyanto, Handoyo, and Fajarwati (2008)explains that a village is a legal community unit that has an original composition based on special rights of origin. It is based on diversity, participation, autonomy, democratization, and community empowerment. So, people in the village should be involved and participate in development because this can be a measure of success in village development, especially those that will make the village a tourist destination.

The legal rules that apply in the village when developing tourism are without prejudice to local communities' traditions and customs. Through preserved culture, people can generate a sense of love for the environment so that authenticity is guaranteed. It is not certain that other villages find the uniqueness of the village itself. This means that the law can be taken firmly to produce a policy that protects the nation's culture. This is the basis of ecotourism, including preserving natural resources.

\section{RESEARCH METHODS}

The data collection method is divided into primary data collection methods and secondary data. Primary data is collected by observation, interview, and questionnaire methods, while secondary data is collected by interviewing the agencies. In taking the sample, a purposive sampling method was used to determine interview sources, namely the Village Head and the Head of the Tourism Office South Bangka Regency; because it is assumed that they master the material, a random sampling method is used to determine the questionnaire respondents, namely 50 respondents from Permis Village and 50 Village respondents so that the number of respondents for the questionnaire is 100 respondents.

The analytical methods used in this research are quantitative and qualitative methods carried out with descriptive statistical analysis methods for the results of the questionnaire, scoring analysis on aspects of tourism objects and attractions and social aspects, and qualitative descriptiveanalysisforthefinalassessment of the potential of community-based ecotourism in the village area. Permis and RajikVillage.

The analysis process is carried out by the research 
objectives, namely by the following types of analysis. Analysis of tourist objects and attractions aims to determine the potential aspects of tourist objects and attractions (ecotourism potential) in the Permis and Rajik villages, carried out using descriptive statistical methods and scoring. These analysis results are descriptions and maps of potential tourist objects and attractions in the study area. The social analysis aims to determine the potential of social aspects and community activeness in the Permis and Rajik villages, carried out using descriptive statistical methods and scoring. The results of this analysis are descriptions and maps of community potential in the study area. The community strengthening examination points to decide the angles of community strengthening and community activeness within the Permis and Rajik towns, related to the significance of this to community-based ecotourism improvement, which is carried out employing a clear subjective strategy based on the comes about of interviews to describe the potential perspectives of community strengthening within the consider zone.

\section{RESULTS AND DISCUSSION}

\section{Aspect of Tourist Attraction}

The analysis of tourism attractiveness in this study was carried out on five variables: tourist attraction, accessibility, transportation providers, environmental conditions, and supporting infrastructure. To assess tourist attractiveness, three indicators are used, namely the type of tourist attraction, the number of tourist objects, and the community's culture. Natural panoramas and their beauty are a type of tourist attraction in the village in the study area, with natural panoramas in Pekapur beach, different rock beaches, hot springs, and rock waterfalls. $40.2 \%$ of respondents stated that the recreation area is a type of tourist attraction that is quite good and has panoramic beauty. On average, there are 1-3 tourist objects in each village based on the answers from $82.5 \%$ of respondents. Because it is still classified as a traditional area, there are still several traditional ceremonies, and regional arts preserved and are still being held in every village.

Accessibility is assessed by indicators of distance from main roads and distance from the city center. $43 \%$ of respondents stated that their village is more than $3 \mathrm{~km}$ from their main road, which is the main road from the village of Permis to the monitoring of the Batubedaun and the waterfall of the rock, while $57 \%$ stated that their village is very close to the main road, namely Kases from Rajik to the beach of BatuBerlianun and a rock waterfall. However, Permis village is very close to Bukit Ninek, which is the Geopark of South Bangka Regency. For the distance from the city center, Permis Village is the closest, which is $64.6 \mathrm{~km}$, and Rajik Village is the farthest, which is $75.2 \mathrm{~km}$. In this accessibility, the respondents complained about the damaged roads in the border villages between districts, thus hampering the tourist arrivals.
The largest number of public transportation providers to and from the study area were Damri Buses, which was started by $53.2 \%$ of respondents. The rest answered buses and other public transportation facilities, such as village transportation. As for the availability of culinary delights, $48.2 \%$ of respondents stated that each village has food stalls. The low availability of culinary delights is due to the fact that MSMEs in each village are quite low; this is because the community has low willingness due to mining is still a priority in the work of the surrounding community.

Environmental conditions are assessed by four indicators, namely village regulations regarding the environment, environmental sanctions, forms of environmental awareness, and the economic value of the environment. As many as $70.3 \%$ of respondents stated that the form of environmental awareness is to maintain the cleanliness of the environment because there is still a lot of rubbish and people's ignorance in maintaining the cleanliness of the tourism object's environment. The form of environmental awareness in the study area is the holding of community service regularly. Meanwhile, for the economic value obtained by the community, as many as $29.7 \%$ of respondents stated that there had been no direct influence on this tourist attraction because the management of these tourist objects has not been formed, so that packaging and promotion have not gone well.

The conditions of clean water, energy (electricity), telecommunications (signals), and sanitation in all villages are in poor and unfavorable conditions. Signals and electricity still need attention from the government because there are still frequent blackouts in Permis and Rajik villages.

Potential of Community Based Ecotourism The overlay results from the ODTW aspect scoring and social aspects were used to map the potential for ecotourism in the Permis and Rajik villages spatially, namely by the category of villages with the highest eco-tourism potential at BaruBedaun Beach, Hot Springs, Batu Waterfall, Bukit Ninek, KulinerLempah Yellow.

The "community-based" or "community- based" concept, the management aspect, and the implementation aspect of community empowerment are the primary considerations because the concept emphasizes high community control. Based on the analysis results, for the management aspect, the community still complains a lot about the lack of community participation and activeness in tourism activities even though the village government has made a concept map for tourism village planning. There is still no complete infrastructure repair, be it infrastructure in the village's tourist objects or infrastructure. Based on the analysis results, the potential for community-based eco-tourism in Permis and Rajik villages is divided into four village categories, namely villages with eco-tourism potential, 
towns with community-based, villages with community-based eco-tourism potential, and villages that do not yet have potential. These potentials, which are spatially mapped in Figure 2.

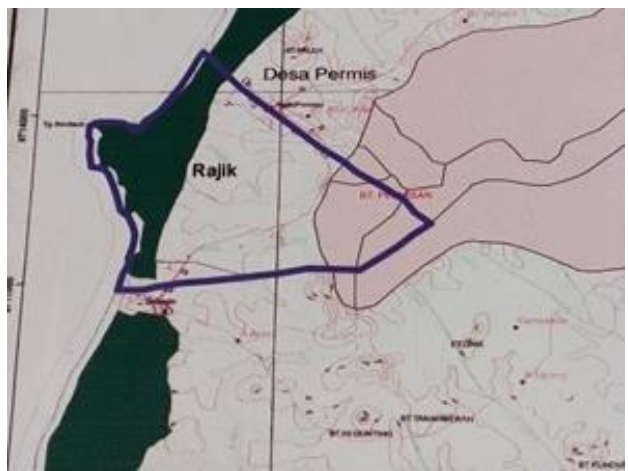

Fig. 2. Tourism Village Planning Conclusion

Based on the results of the analysis, it can be concluded that the Permis Village and Rajik Village areas represented by BatuBedaun Beach, Hot Springs, Batu Waterfalls, Bukit Ninek Tourism, LempahKuning have good potential to be developed as community-based ecotourism areas because they do not only have tourism resources in the form of natural and cultural tourism but also has potential community resources to be empowered in these tourism activities. There are moreover a few government programs and approaches to create ecotourism within the zone.

\section{CONCLUSIONS}

Rajik Village and Peermis Village, SimpangRimba Subdistrict, South Bangka Regency are villages that have potential which have not been well managed so far. Like local tourism potential, this village is directly adjacent to the sea, surrounded by granite stones, hills overgrown with dense natural forests to the food and crafts of the people. The local village government has now started to open access for local tourism. Through the youth organization and the community, they actively work together. There are several tourist destinations in the village that will be developed, namely Kik Antak Beach and Rock (a stone shaped like a hat)
In increasing promotion, DesaRajik now has a website; just type in google rajik.id anyone can see everything in this village. Village websites are necessary, especially in this day and age, fast and accurate information is crucial. Its purpose is as information to also facilitate the community. Within the future, it too does not run the show out the plausibility of being able to advance the potential that exists in this town.

\section{REFERENCES}

[1] Ismayanti, Pengantar Pariwisata. Jakarta: PT. Gramedia Widiasarana Indonesia, 2010.

[2] R. S. Wardhani and D. Valeriani, "Green Tourism Dalam Pengembangan Pariwisata Bangka Belitung," Pros. Semin. Nas. INDOCOMPAC, 2016.

[3] P. Mason, Tourism impacts, planning and management. 2012.

[4] C. A. Gunn, Vacationscape: Developing tourist areas. 2014

[5] C. A. Gunn, "Prospects for Tourism Planning: Issues and Concerns," J. Tour. Stud., 2004.

[6] R. Fajriasanti, "Pariwisata Sebagai Sistem: Model Sistem Pariwisata di Kabupaten Klaten Propinsi Jawa Tengah," Institut Teknologi Bandung, 2010.

[7] A. Lew and B. McKercher, "Modeling tourist movements: A local destination analysis," Ann. Tour. Res., 2006, doi: 10.1016/j.annals.2005.12.002.

[8] I. A. Jamalina and D. T. K. Wardani, "Strategi Pengembangan Ekowisata Melalui Konsep Community Based Tourism (Cbt) Dan Manfaat Sosial Dan Ekonomi Bagi Masyarakat Di Desa Wisata Nglanggeran, Patuk, Gunung Kidul," J. Ekon. Stud. Pembang., 2017, doi: 10.18196/jesp.18.1.4008.

[9] P. Suansri, "Community based tourism handbook," in Community Based Tourism Handbook, 2003.

[10] I. Mualisin, "Model Pengembangan Pariwisata Berbasis Masyarakat Di Kota Yogyakarta," Maj. Ilm. Pembelajaran, 2017.

[11] E. Okazaki, "A community-based tourism model: Its conception and use," Journal of Sustainable Tourism. 2008, doi: $10.2167 /$ jost782.0.

[12] D. W. Susyanti, "Potensi Desa melalui Pariwisata Pedesaan," Ekon. dan Bisnis, 2014, doi: 10.1152/ajpheart.00083.2011.

[13] N. Komariah, E. Saepudin, and P. M. Yusup, "Pengembangan Desa Wisata Berbasis Kearifan Lokal," J. Pariwisata Pesona, 2018, doi: 10.26905/jpp.v3i2.2340.

[14] Suwantoro, "Dasar-Dasar Pariwisata," J. Chem. Inf. Model., 2002.

[15] Hartini, Ilmu Pariwisata. 2011.

[16] Permendagri Nomor 33, "Pedoman Pengembangan Ekowisata Di Daerah," Kementeriaan Dalam negeri Republik Indones. 2009.

[17] D. Widiyanto, J. P. Handoyo, and A. Fajarwati, "Pengembangan Pariwisata Perdesaan (Suatu Usulan Strategi Bagi Desa Wisata Ketingan)," J. Bumi Lestari, 2008. 